\title{
Faktor yang mempengaruhi keputusan pengambilan kredit konsumtif pada aparatur sipil negara Kecamatan Lumajang
}

\author{
Rangga Adi Caksana, Dwi Wulandari* \\ Universitas Negeri Malang, Jl. Semarang No. 5 Malang, Jawa Timur, Indonesia \\ *Penulis korespondensi, Surel: dwi.wulandari.fe@um.ac.id
}

Paper received: 25-8-2021; revised: 8-9-2021; accepted: 15-9-2021

\begin{abstract}
This study aims to explain the influence of financial literacy, the nature of materialism, gender, level of education on consumer credit decision making in the State Civil Apparatus of Lumajang District. The total sampling based on the $10 \%$ slovin formula was 46 people, the sampling in this study used simple random sampling. Based on the results of the $t$ test, it shows that financial literacy and the nature of materialism have a positive and significant effect, while gender and education level have a negative and significant effect.
\end{abstract}

Keywords: financial literacy; the nature of materialism; gender; level of education; consumer credit

\begin{abstract}
Abstrak
Penelitian ini menyelidiki pengaruh dari literasi keuangan, sifat materialisme, jenis kelamin, dan tingkatan pendidikan, pada pengambilan keputusan kredit para konsumen yang merupakan pegawai negeri sipil di Kabupaten Lumajang. Sejumlah 46 orang sampel diambil menggunakan rumus $10 \%$ Slovin dan simple random sampling. Hasil dari uji t menunjukkan bahwa literasi keuangan dan sifat materialism memiliki efek yang positif dan signifikan, sedangkan jenis kelamin dan tingkat pendidikan menunjukan efek negative dan signifikan.
\end{abstract}

Kata kunci: literasi keuangan; sifat materialism; jenis kelamin; tingkat pendidikan; kredit konsumen.

\section{Pendahuluan}

Manusia melakukan transaksi untuk memenuhi kebutuhan sehari-hari dalam menjalani kelangsungan hidup. Bertransaksi mengakibatkan terjadinya perputaran keuangan baik bertambah ataupun berkurang. Transaksi dapat berarti membeli sesuatu baik secara offline atau online. Transaksi offline seperti membeli barang di pasar dengan cara cash, sedangkan transaksi online seperti membeli barang di marketplace, internet, dan sosial media dengan cara pembayaran menggunakan kartu kredit. Kartu kredit mempunyai kelebihan yang ditawarkan oleh bank kepada nasabah. Kelebihan ini menarik minat konsumen sehingga konsumen percaya dan sering menggunakan kartu kredit dalam bertransaksi. Kelebihan yang ditawarkan berupa penggunaan yang praktis, mudah, aman, dan nyaman karena dapat menghemat tenaga dan waktu. Pihak perbankan melakukan pemberian reward kepada nasabah seperti cashback dan menambahkan poin apabila bertransaksi menggunakan kartu kredit. Kartu kredit mempunyai fitur pemblokiran apabila hilang sehingga nasabah dapat terlindungi dari penyalahgunaan. Perkembangan teknologi membuat kartu kredit sebagai transaksi gaya hidup modern, sehingga penggunanya merubah persepsi hutang menjadi gengsi.

Perkembangan pembayaran non tunai berbasis kartu kredit telah berkembang pesat sesuai dengan kemajuan teknologi. Di Indonesia sendiri dalam periode 2016-2020 tercatat dari databoks yang bersumber dari Bank Indonesia, transaksi pada tahun 2016 sebesar Rp 281 
triliun, meningkat pada tahun 2017 menjadi Rp297, 8 triliun, tahun 2018 berjumlah Rp 314, 3 triliun, tahun 2019 berjumlah 342, 7 triliun, dan mengalami penurunan pada tahun 2020 menjadi Rp 54,5 triliun. Melalui perbankan, semua orang berkesempatan memperoleh barang yang di inginkan melalui kredit untuk kebutuhan yang tidak bisa mereka penuhi, sehingga tidak perlu khawatir jika tidak memiliki cukup uang. Salah satu jenis kredit untuk memenuhi kebutuhan manusia untuk keperluan konsumsi adalah kredit konsumtif. Kredit konsumtif adalah kredit yang diberikan pihak bank atau lembaga keuangan bukan bank kepada nasabah dengan tujuan untuk dikonsumsi sendiri. Kredit konsumtif biasanya berupa barang-barang yang nilainya tinggi tapi tidak bersifat pokok seperti mobil, motor, barang elektronik / gadget, kredit perabotan rumah tangga, dan lainnya. Kredit konsumtif adalah cara instan karena barang yang dinginkan akan langsung didapat. Melalui kredit konsumtif, barang yang dibutuhkan akan terpenuhi tanpa harus menunggu uang terkumpul untuk membeli barang yang akan dikonsumsi secara pribadi, dengan mengajukan kredit konsumtif pada bank umum maupun bank syariah. Kemudahan memperoleh dana yang didapat nasabah dengan melakukan pembelian terlebih dahulu dengan catatan membayar pada saat tanggal jatuh tempo membuat minat nasabah bertambah untuk menggunakan kartu kredit. Penggunaan kartu kredit berbeda jauh dengan kartu debet, tanggung jawab dan kesadaran nasabah sangat dibutuhkan ketika menggunakannya, sehingga tidak menimbulkan gagal bayar.

Berdasarkan survei yang dilakukan Bank Indonesia pertumbuhan triwulan kredit baru melambat pada triwulan I-2020. Hal itu tercermin dari saldo bersih tertimbang (SBT) permintaan kredit baru pada triwulan I-2020 sebesar 23,7\%. Berdasarkan jenis penggunaan, melambatnya pertumbuhan permintaan kredit baru bersumber dari seluruh jenis kredit, dengan penurunan terbesar pada jenis kredit konsumsi. Pada triwulan ke II Bank Indonesia mengindikasikan pertumbuhan kredit menurun dari periode sebelumnya, tercermin dari saldo bersih tertimbang (SBT) permintaan kredit baru pada triwulan II-2020 sebesar -33.9\%. Pada triwulan III Bank Indonesia mengindikasikan bahwa tercermin dari saldo bersih tertimbang (SBT) permintaan kredit baru pada triwulan III-2020 sebesar 50,6\%, lebih baik dibandingkan dengan $-33,9 \%$ pada triwulan sebelumnya. Pada triwulan IV-2020, pertumbuhan kredit baru diprakirakan meningkat, meski tidak setinggi periode yang sama pada tahun sebelumnya. Hasil survei mengindikasikan pertumbuhan kredit melambat untuk keseluruhan tahun 2020. Responden memprakirakan pertumbuhan kredit pada 2020 sebesar 2,5\% (yoy), lebih rendah dibandingkan dengan realisasi kredit pada 2019 sebesar 6,1\% (yoy).

Pembayaran menggunakan kartu kredit memberikan perubahan perilaku individu dalam hal pola berbelanja, sehingga individu membuat keputusan untuk mengambil suatu kredit. sebagaimana telah diungkapkan oleh (Hafizhah et al., 2016), yaitu orang yang memiliki sifat materialisme cenderung ingin memiliki banyak uang untuk memenuhi kebutuhannya akan barang-barang mewah sebagai ajang menunjukkan jati dirinya. Keinginan untuk memiliki uang banyak berarti memiliki kecintaan yang tinggi terhadap uang, tingkat kecintaan yang tinggi terhadap uang akan memungkinkan untuk mengambil kredit konsumtif. Konsumen yang memiliki sifat materialisme tinggi cenderung melakukan kegiatan konsumsi irasional memiliki kecenderungan membeli merek terkenal, mengutamakan gengsi dan prestige sehingga kondisi keuangan pribadi tidak tertata menyebabkan pengambilan keputusan untuk melakukan kredit. Materialisme memberikan dampak buruk bagi masyarakat dalam kecenderungan membeli. Pembelian barang-barang yang berlebihan dan seringnya individu kehilangan kontrol atas pembelian tersebut menjadikan individu sebagai pembeli kompulsif (Mueller et al., 2011). Individu yang memiliki sifat materialisme akan menghabiskan banyak uang untuk membeli 
banyak barang apabila mengalami kekurangan dana yang disebabkan lemahnya pengetahuan dalam mengelola keuangan akan melakukan transaksi pembelian secara kredit. Individu yang memiliki sifat materialisme kurang memperhatikan antara keinginan semata dan kebutuhan yang wajib dipenuhi.

Kemampuan pengetahuan literasi keuangan membuat individu bisa mencapai kesejahteraan finansial serta memahami keuntungan dan resiko setiap produk kredit yang memberikan kesejahteraan keuangan di masa yang akan datang. Pada literasi keuangan, terdapat 2 unsur yang bisa mempengaruhi sesorang dalam mengajukan kredit yaitu money management dan saving. Literasi keuangan merupakan pemahaman dasar seseorang tentang pengelolaan keuangan mulai dari pendapatan maupun pengeluaran untuk membuat keputusan yang benar dalam lingkup keuangan untuk meningkatkan taraf kesejahteraan hidup. Konsumen yang mengerti literasi keuangan akan menggunakan pendapatan yang diperolehnya secara rasional, sedangkan konsumen yang tidak memahami literasi keuangan akan menggunakan pendapatannya secara irasional. Konsumen yang rasional mampu membuat keputusan dengan cara melakukan kegiatan konsumsi sesuai produk yang memberikan kepuasan dengan nilai guna yang optimal, produk memang benar-benar dibutuhkan, kualitas dan harga produk sesuai dengan kemampuan yang dimilikinya. Menurut (Chinen \& Endo, 2012) mengatakan bahwa individu yang memiliki kemampuan untuk membuat keputusan yang benar tentang keuangan tidak akan memiliki masalah keuangan dimasa depan dan menunjukkan perilaku keuangan yang sehat serta mampu menentukan prioritas kebutuhan bukan keinginan.

Selain literasi keuangan dan sifat materialisme terdapat juga faktor yang mempengaruhi pengambilan kredit konsumtif yaitu gender dan tingkat pendidikan. Pada variabel gender dan tingkat pendidikan terdapat perbedaan yang dapat mempengaruhi perilaku seseorang dalam mengelola keuangannya. Gender antara laki-laki dan perempuan merupakan pembeda dari fisik secara biologis dalam kehidupan sosial, tetapi bisa sama atau berbeda dalam hal karakteristik, watak, perilaku, kebiasaan dan peran dalam rumah tangga. Perbedaan tersebut membuat antara laki-laki dan perempuan memiliki sifat yang berlainan dalam hal mengatur keputusan keuangan dan berbelanja menggunakan kartu kredit. Pendidikan merupakan tingkat pemahaman seseorang terhadap ilmu pengetahuan tentang bagaimana memahami sesuatu hal. Perbedaan tingkat pendidikan membuat individu berbeda pula dalam hal menyikapi keputusan pengambilan suatu kredit. Semakin tinggi tingkat pendidikan individu, maka semakin pula bijak dalam mengatur keuangan pribadi dan mengetahui manfaat dari kredit yang mereka ambil dan begitu pula sebaliknya.

Kabupaten Lumajang merupakan salah satu daerah yang berada di wilayah bagian selatan Provinsi Jawa Timur. Dalam menjalankan pelayanan publik dan administrasi pemerintahan Kabupaten Lumajang terbagi menjadi 21 wilayah Kecamatan. Berdasarkan data yang ada di website resmi Badan Kepegawaian Daerah Pemerintah Kabupaten Lumajang, jumlah seluruh Aparatur Sipil Negara yang bertugas di tingkat kecamatan sebagai berikut: Kecamatan Lumajang; 59, Sukodono; 12, Senduro; 14, Gucialit; 14, Padang; 12, Pasrujambe; 12 , Klakah; 14, Ranuyoso; 12, Randuagung; 12, Kedungjajang; 13, Yosowilangun; 11, Jatiroto; 10 , Rowokangkung; 12, Kunir; 14, Tekung;9, Pasirian; 11, Tempeh; 14, Candipuro; 15, Pronojiwo; 14, Tempursari; 11, dan Sumbersuko; 13. Kecamatan Lumajang merupakan salah satu kecamatan yang ada di Kabupaten Lumajang dan berfungsi sebagai pusat kegiatan ekonomi dan pemerintahan dengan luas 30,26 km2. Berdasarkan data di website Badan Kepegawaian 
Daerah Kabupaten Lumajang bahwa Kecamatan Lumajang memiliki jumlah Aparatur Sipil Negara terbanyak yaitu 59 orang, tetapi berdasarkan fakta hasil observasi di lapangan jumlah Aparatur Sipil Negara sebesar 86, hal tersebut dikarenakan data dari website kurang terupdate serta adanya mutasi, pensiun, dan penambahan Aparatur Sipil Negara. Sebagaimana diatur dalam Undang-Undang Republik Indonesia Nomor 5 Tahun 2014 Tentang Aparatur Sipil Negara Pasal 21, Aparatur Sipil Negara berhak memperoleh: gaji, tunjangan, dan fasilitas; cuti; jaminan pensiun dan jaminan hari tua; perlindungan; dan pengambangan kompetensi. Minimnya gaji yang diterima mengakibatkan banyak penawaran kredit yang diberikan oleh pihak bank diambil oleh Aparatur Sipil Negara untuk memenuhi kebutuhan baik yang bersifat primer atau sekunder.

Peningkatan permintaan pengambilan kredit konsumtif menunjukkan bahwa individu mengalami masalah keuangan yang parah, oleh karena itu penelitian ini ingin mengetahui pengaruh faktor-faktor yang berkontribusi terhadap keputusan pengambilan kredit konsumtif. Dimana objek yang digunakan adalah lembaga pemerintahan yaitu Aparatur Sipil Negara Kecamatan Lumajang, alasannya karena berdasarkan fakta yang ditemukan dari hasil observasi, terdapat permintaan kredit konsumtif sebesar 54 orang pada bulan April tahun 2020. Kemudahan pengambilan kredit yang diberikan oleh pihak perbankan kepada Aparatur Sipil Negara, yaitu karena ketika mengalami kondisi gagal bayar bisa membayar kredit tersebut dengan pemotongan gaji bulanan yang dilakukan oleh pihak bank melalui juru bayar gaji / bendahara. Sejalan dengan penelitian yang dilakukan oleh (Hadad et al., 2004), probabilitas rumah tangga memiliki kredit juga akan lebih besar jika kepala rumah tangga memiliki pekerjaan sebagai pegawai negeri sipil, pegawai swasta/BUMN atau berusaha dengan buruh dibandingkan dengan kepala keluarga yang berusaha tanpa buruh. Berdasarkan latar belakang yang telah diuraikan penelitian ini berjudul :"Faktor Yang Mempengaruhi Keputusan Pengambilan Kredit Konsumtif Aparatur Sipil Negara Kecamatan Lumajang".

Berdasarkan latar belakang yang telah diuraikan di atas, maka penulis dapat merumuskan masalah sebagai berikut: (1) Bagaimana pengaruh literasi keuangan terhadap keputusan pengambilan kredit konsumtif pada Aparatur Sipil Negara Kecamatan Lumajang? (2) Bagaimana pengaruh sifat materialisme terhadap keputusan pengambilan kredit konsumtif pada Aparatur Sipil Negara Kecamatan Lumajang? (3) Bagaimana pengaruh gender terhadap keputusan pengambilan kredit konsumtif pada Aparatur Sipil Negara Kecamatan Lumajang? (4) Bagaimana pengaruh tingkat pendidikan terhadap keputusan pengambilan kredit konsumtif pada Aparatur Sipil Negara Kecamatan Lumajang?

Berdasarkan rumusan masalah diatas, maka tujuan dalam penelitian ini dapat dirumuskan sebagai berikut: (1) Mengetahui pengaruh literasi keuangan terhadap keputusan pengambilan kredit konsumtif pada Aparatur Sipil Negara Kecamatan Lumajang. (2) Mengetahui pengaruh sifat materialisme terhadap keputusan pengambilan kredit konsumtif pada Aparatur Sipil Negara Kecamatan Lumajang. (3) Mengetahui pengaruh gender terhadap keputusan pengambilan kredit konsumtif pada Aparatur Sipil Negara Kecamatan Lumajang.

Mengetahui pengaruh tingkat pendidikan terhadap keputusan pengambilan kredit konsumtif pada Aparatur Sipil Negara Kecamatan Lumajang.

Literasi Keuangan menurut (Lusardi \& Mitchell, 2014) dalam jurnal (Yushita, 2017), menyatakan bahwa literasi keuangan terdiri dari sejumlah kemampuan dan pengetahuan mengenai keuangan yang dimiliki oleh seseorang untuk mampu mengelola atau menggunakan 
sejumlah uang untuk meningkatkan taraf hidupnya dan bertujuan untuk mencapai kesejahteraan. Literasi keuangan sangat terkait dengan perilaku, kebiasaan dan pengaruh dari faktor eksternal.

Menurut (Mason \& Wilson, 2000) dalam jurnal (Yushita, 2017), Literasi keuangan didefinisikan sebagai kemampuan seseorang untuk mendapatkan, memahami dan mengevaluasi informasi yang relevan untuk pengambilan keputusan dengan memahami konsekuensi finansial yang ditimbulkan.

Menurut (Chen \& Volpe, 1998), Literasi keuangan mencakup beberapa aspek keuangan yang harus dikuasai. Terdapat beberapa aspek-aspek yang digunakan untuk mengetahui tingkat pengetahuan keuangan seseorang yaitu saving, borrowing and investment, income, insurance, and money management.

Literasi keuangan adalah cara terbaik untuk mengajarkan konsumen tentang manfaat memiliki hubungan dengan lembaga keuangan diantaranya adalah pendanaan dan kredit, kemampuan untuk membangun keuangan yang positif (Rohrke \& Robinson, 2000).

Materialisme menurut (Schiffman \& Kanuk, 2008), sifat materialisme merupakan kepribadian membedakan antara individu yang menganggap kepemilikan barang sangat penting bagi identitas dan kehidupan mereka, dan orang-orang yang menganggap kepemilikan barang merupakan hal yang sekunder. Para peneliti telah menemukan hal-hal yang mendukung ciri-ciri orang-orang yang materialisti seperti berikut ini: (1) mereka sangat menghargai barang yang dapat diperoleh dan dapat dipamerkan; (2) mereka sangat egosentris dan egois; (3) mereka mencari gaya hidup dengan banyak barang (misalnya, mereka ingin mempunyai berbagai "barang", bukannya gaya hidup yang teratur dan sederhana saja), dan (4) kebanyakan milik mereka tidak memberikan kepuasan pribadi yang lebih besar (maksudnya, barang-barang milik mereka tidak memberikan kebahagiaan yang lebih besar).

Sifat materialisme umumnya dimiliki oleh semua lapisan masyarakat. Sejalan dengan hal itu, menurut (Winatha \& Sukaatmadja, 2014), sifat materialisme merupakan salah satu sifat individu masyarakat di dunia, termasuk masyarakat Indonesia.

Menurut (Iqbal \& Aslam, 2016), materialisme diartikan sebagai cara individu guna memperoleh uang, status, dan barang-barang, hal tersebut merupakan kombinasi dari berbagai prinsip yang membuat tujuan materialistis sebagai simbol dari pencapaian, sedangkan barang-barang dipertimbangkan sebagai bagian penting dari kehidupan dan semakin banyak barang akan menyediakan kepuasan yang lebih.

Kata Gender berasal dari bahasa Inggris berarti "jenis kelamin". Menurut (Neufeldt, 2002) dalam Webster's New World Dictionary, gender diartikan sebagai perbedaan yang tampak antara laki-laki dan perempuan dilihat dari segi nilai dan tingkah laku.

Gender menurut (Collins, 1988) , melihat stratifikasi gender dalam, dari sudut kelas sosial yaitu pemberi perintah dan penerima, perintah. Kedua kelas ini muncur sebagai akibat dari tuntutan kultur masyarakat yang menempatkan perempuan dan laki- laki pada posisi yang sama. stratifikasi ini mengakibatkan status dan posisi perempuan dalam keluarga cenderung lebih banyak mencurahkan waktunya untuk kegiatan home production, sementara laki-laki banyak berkonsentrasi pada aktivitas produksi dan hubungan-hubungan kekuasaan. 
Adapun hubungan yang terjadi antara gender dan pengambilan keputusan menurut (Handayani et al., 2008), bahwa gender adalah sebagai konsep sosial yang membedakan (dalam artian memisahkan) peran pria dan wanita, bersifat dapat dipertukarkan, tidak ditentukan oleh perbedaan biologis atau kodrat melainkan dibedakan atau dipilah menurut kedudukan, fungsi, peranan masing-masing di lingkungan kerja/sosial.

Tingkat Pendidikan Menurut Undang-undang Republik Indonesia No. 20 tahun 2003 tentang sistem Pendidikan Nasional Pasal 1 ayat 1 yaitu "pendidikan adalah usaha sadar dan terencana untuk rasional, kreatif dan sistematis. Dengan pendidikan dapat memperluas keilmuan, meningkatkan kemampuan dan potensi serta membuat seseorang lebih peka terhadap setiap gejala-gejala sosial yang muncul.

Berdasarkan UU No. 20 tahun 2003, sesuai pasal 17-19 tingkat pendidikan formal terdiri atas pendidikan dasar, pendidikan menengah, dan pendidikan tinggi.

Pasal 17 pendidikan dasar, terdiri dari: (1) Pendidikan dasar merupakan jenjang pendidikan yang melandasi jenjang pendidikan menengah. (2) Pendidikan dasar berbentuk Sekolah Dasar (SD) dan Madrasah Ibtidaiyah (MI) atau bentuk lain yang sederajat serta Sekolah Menengah Pertama (SMP) dan Madrasah Tsanawiyah (MTs), atau bentuk lain yang sederajat. (3) Ketentuan mengenai pendidikan dasar sebagaimana dimaksud dalam ayat 1 dan ayat 2diatur lebih lanjut dengan Peraturan Pemerintah.

Pasal 18 pendidikan menengah, terdiri dari: (1) Pendidikan menengah merupakan lanjutan pendidikan dasar. (2) Pendidikan menengah terdiri atas pendidikan menengah umum dan pendidikan menengah kejuruan. (3) Pendidikan menengah berbentuk Sekolah Menengah Atas (SMA), Madrasah Aliyah (MA), Sekolah Menengah Kejuruan (SMK), dan Madrasah Aliyah Kejuruan (MAK), atau bentuk lain yang sederajat. (4) Ketentuan mengenai pendidikan menengah sebagaimana dimaksud dalam ayat 1 , ayat 2 , dan ayat 3 diatur lebih lanjut dengan Peraturan Pemerintah.

Pasal 19 pendidikan tinggi, terdiri dari: (1) Pendidikan tinggi merupakan jenjang pendidikan setelah pendidikan menengah yang mencakup program pendidikan diploma, sarjana, magister, spesialis, dan doktor yang diselenggarakan oleh perguruan tinggi.Institut. (2) Pendidikan tinggi diselenggarakan dengan sistem terbuka.

Menurut (Zahara, 1981), juga mengemukakan bahwa pendidikan formal terdiri dari pendidikan dasar, menengah dan tinggi. (1) Pendidikan dasar : SD dan SMP (2) Pendidikan menengah : SMA dan SMK (3) Pendidikan tinggi : diploma, sarjana, magister, doktor dan spesialis.

Dalam Kredit Konsumtif keputusan nasabah dalam mengambil kredit, sangat penting sebelum nasabah mengambil kredit yang terdapat di lembaga keuangan. Keputusan bermaksud untuk menghindari hambatan baik besar maupun yang kecil, sehingga perlu diambil suatu keputusan. Keputusan yang diambil juga dapat menimbulkan efek dan memunculkan masalah pada bidang yang lain, sehingga saat mengambil keputusan harus cermat dalam hal seperti ini agar mendekati tujuan yang telah direncanakan sebelumnya (Tsalitsa \& Rachmansyah, 2016). 
Aparatur Sipil Negara rata-rata merupakan golongan kelas sosial menenga keatas dan mengah kebawah. Apabila Aparatur Sipil Negara Mengambil Kredit tidak mampu untuk membayarnya, maka pihak bank bisa melakukan pemotongan melalui gaji mereka secara penuh setiap bulan sampai kredit tersebut lunas. Sejalan dengan hal itu, menurut (Schiffman \& Kanuk, 2008), Simpanan, pengeluaran, dan pemakaian kartu kredit tampaknya ada hubungannya dengan kedudukan kelas sosial.

Menurut (Phillip Kotler, 2008), mengungkapkan bahwa indikator keputusan pengambilan kredit oleh nasabah yaitu: (1) Persepsi melihat kinerja/performace karyawan. Mengenai bagaimana kinerja karyawan apakah karyawan bekerja dengan benar sesuai prosedur ataukah banyak kesalahan yang dilakukan karyawan, sehingga mengganggu proses pengambilan kredit pada suatu lembaga keuangan. (2) Kepuasan akan kredit yang ditawarkan. Penawaran kredit yang sesuai dengan kebutuhan nasabah akan memberikan kepuasan bagi nasabah yang memutuskan untuk mengambil kredit pada suatu lembaga keuangan. (3) Penyediaan informasi pada saat diminta. Penyampaian informasi yang baik oleh suatu lembaga keuangan ketika proses pengambilan kredit akan memudahkan nasabah dalam proses kredit yang dilakukan sesuai dengan yang diharapkan. (4) Kepercayaan terhadap kelompok referensi. Kelompok referensi atau reference group yang dimiliki oleh nasabah akan memberikan pengaruh terhadap kepercayaan nasabah untuk mengambil kredit pada lembaga keuangan yang diyakini oleh kelompok tersebut. (5) Pertimbangan pelayanan. Pelayanan prima yang diberikan oleh lembaga keuangan, akan mempengaruhi keputusan nasabah dalam mengambil kredit pada suatu lembaga keuangan tersebut dikemudian hari.

Aparatur Sipil Negara, menurut Undang-Undang Republik Indonesia Nomor 5 Tahun 2014 Tentang Aparatur Sipil Negara, Bab 1 yang berbunyi: (1) Aparatur Sipil Negara yang selanjutnya disingkat ASN adalah profesi bagi pegawai negeri sipil dan pegawai pemerintah dengan perjanjian kerja yang bekerja pada instansi pemerintah. (2) Pegawai Aparatur Sipil Negara yang selanjutnya disebut Pegawai ASN adalah pegawai negeri sipil dan pegawai pemerintah dengan perjanjian kerja yang diangkat oleh pejabat pembina kepegawaian dan diserahi tugas dalam suatu jabatan pemerintahan atau diserahi tugas negara lainnya dan digaji berdasarkan peraturan perundang-undangan. (3) Pegawai Negeri Sipil yang selanjutnya disingkat PNS adalah warga negara Indonesia yang memenuhi syarat tertentu, diangkat sebagai Pegawai ASN secara tetap oleh pejabat pembina kepegawaian untuk menduduki jabatan pemerintahan, dan lain-lain.

Berdasarkan teori-teori yang dikemukakan, maka selanjutnya dapat digunakan untuk Menyusun kerangka beripikir. Dengan kerangka berpikir ini selanjutnya dapat digunakan untuk menyusun hipotesis. Hipotesis merupakan jawaban sementara terhadap rumusan masalah atau sub maslah yang diajukan oleh peneliti, yang dijabarkan dari landasan teori atau kajian teori dan masih harus diuji kebenarannya (Riduwan, 2010).

Hipotesis yang akan diterapkan oleh peneliti sebagai berikut: (1) Terdapat pengaruh literasi keuangan terhadap keputusan pengambilan kredit konsumtif. (2) Terdapat pengaruh siifat materialisme terhadap keputusan pengambilan kredit konsumtif. (3) Terdapat pengaruh gender terhadap keputusan pengambilan kredit konsumtif. (4) Terdapat pengaruh tingkat pendidikan terhadap keputusan pengambilan kredit konsumtif 


\section{Metode}

\subsection{Populasi}

Populasi dalam penelitian ini adalah aparatur sipil negara (ASN) yang bekerja di instansi pemerintah Kecamatan Lumajang termasuk 7 kelurahan antaralain; Kelurahan Citrodiwangsan, Kelurahan Ditotrunan, Kelurahan Jogotrunan, Kelurahan Jogoyudan, Kelurahan Rogotrunan, Kelurahan Tompokersan, Kelurahan Kepuharjo, yang berada di Kabupaten Lumajang. Jumlah Aparatur Sipil Negara Kecamatan Lumajang yaitu berjumlah 86 orang.

\subsection{Sampel}

Sampel dalam penelitian ini ditentukan berdasarkan Rumus Slovin dengan taraf signifikansi $10 \%$, yaitu sebagai berikut:

$$
\begin{gathered}
n=\frac{N}{1+N \cdot e^{2}} \\
n=\frac{86}{1+86 \cdot\left(0,1^{2}\right)} \\
n=\frac{86}{1,86} \\
\mathrm{n}=46,23 \text { dibulatkan } 46
\end{gathered}
$$

Dari perhitungan tersebut, disimpulkan bahwa jumlah sampel yang digunakan dalam penelitian ini adalah 46 orang.

\subsection{Sampling}

Teknik pengambilan sampling dalam penelitian ini menggunakan simple random sampling. Simple random sampling adalah cara pengambilan sampel dari anggota populasi dengan menggunakan acak tanpa memperhatikan strata (tingkatan) dalam anggota populasi tersebut. Hal ini dilakukan apabila anggota populasi dianggap homogen (Riduwan, 2010).

\subsection{Analisis data}

Teknik analisis statistika inferensial yang digunakan dalam penelitian ini adalah analisis regresi linier berganda. Menurut (Setiawan \& Kusrini, 2010), dalam bukunya ekonometrika bahwa analisis regrresi adalah suatu analisis yang bertujuan untuk menunjukkan hubungan matematis antara variabel respons dengan variabel penjelas. Analisis regresi linier berganda digunakan untuk mengetahui pengaruh variabel independen literasi keuangan $\left(\mathrm{X}_{1}\right)$, sifat materialisme $\left(\mathrm{X}_{2}\right)$, gender $\left(\mathrm{X}_{3}\right)$, dan tingkat pendidikan $\left(\mathrm{X}_{4}\right)$ terhadap variabel dependen pengambilan kredit konsumtif $(\mathrm{Y})$. Analisis data dalam penelitian ini menggunakan aplikasi komputer SPSS 25 for Windows. Rumus analisis regresi linier berganda adalah sebagai berikut:

$$
\begin{aligned}
& Y=a+\beta_{1} X_{1}+\beta_{2} X_{2}+\beta_{3} D_{3} \\
& +\beta_{4} D_{4(\text { SMP })}+\beta_{5} D_{4(\text { SMA })} \\
& +\beta_{6} D_{4(\text { strata satu })}+\beta_{7} D_{4(\text { pasca sarjana })} \\
& +\beta_{8} D_{4(\text { doctoral })}+\varepsilon
\end{aligned}
$$

Keterangan:

$\mathrm{Y}=$ variabel terikat 
$a=$ Konstanta

$\beta 1, \beta 2, \beta 3 \beta n$,= Parameter yang akan diestimasi

$\mathrm{X}_{1}=$ Literasi keuangan

$\mathrm{X}_{2}=$ Sifat materialisme

$\mathrm{X}_{3}=$ Gender (laki- laki $=1$, perempuan $=0$ )

$\mathrm{X}_{4}=$ Tingkat pendidikan ( sekolah dasar $=0$, sekolah menengah pertama $=1$, sekolah menengah keatas $=1$, strata satu $=1$, pasca sarjana $=1$, doctoral $=1$ )

$\varepsilon=$ error term

\section{Hasil dan Pembahasan}

\subsection{Hasil}

\subsubsection{Uji Regresi Linier Berganda}

Pengujian regresi linier berganda bertujuan untuk melihat pengaruh antara variabel literasi keuangan $\left(\mathrm{X}_{1}\right)$, sifat materialisme $\left(\mathrm{X}_{2}\right)$, gender $\left(\mathrm{X}_{3}\right)$, tingkat pendidikan $\left(\mathrm{X}_{4}\right)$ terhadap variabel keputusan pengambilan kredit konsumtif $(Y)$. Hasil pengujian regresi linier berganda tersaji pada tabel berikut.

Tabel 1. Uji regresi linier berganda

\begin{tabular}{lccccc}
\multicolumn{1}{c}{ Model } & \multicolumn{2}{c}{$\begin{array}{c}\text { Unstandartdized } \\
\text { Coefficients }\end{array}$} & $\begin{array}{c}\text { Standartdized } \\
\text { Coefficients }\end{array}$ & $\mathrm{t}$ & Sig. \\
& $\mathrm{B}$ & $\begin{array}{c}\text { Std. } \\
\text { Error }\end{array}$ & Beta \\
& 5,316 & 3,898 & & \\
\hline Constant) &, 160 &, 054 &, 388 & 1,364 &, 181 \\
Literasi Keuangan (X1) &, 325 &, 114 &, 428 & 2,851 &, 005 \\
Sifat Meterialisme (X2) &,- 586 &, 565 &,- 142 & $-1,039$ &, 305 \\
Jenis Kelamin (X3) &,- 371 &, 608 &,- 090 &,- 611 &, 544 \\
Tingkat Pendidikan (S1) &, 480 & 1,354 &, 047 &, 354 &, 725 \\
Tingkat Pendidikan (Pasca) &
\end{tabular}

a. Dependent Variable: Keputusan Pengambilan Kredit Kondumtif (Y)

Hasil uji regresi linier berganda pada tabel 3 didapatkan persamaan regresi sebagai berikut:

$+\beta_{5} D_{4(2)}+\varepsilon$

$$
Y=a+\beta_{1} X_{1}+\beta_{2} X_{2}+\beta_{3} D_{3}+\beta_{4} D_{4(1)}
$$

$Y=5,316+0,160 X_{1}+0,325 X_{2}$

$-0,586 D_{3}-0,371 D_{4(s 1)}$

$+0,480 D_{4(\text { pasca })}+\varepsilon$

Berdasarkan persamaan tersebut dapat dijabarkan interpretasi sebagai berikut:

Nilai konstanta (a) sebesar 5,316 memiliki arti apabila seluruh variabel bebas bernilai nol, maka tingkat keputusan pengambilan kredit konsumtif (Y) sebesar 5,316.

Koefisien parameter $\beta_{1}$ pada variabel Literasi Keuangan $\left(\mathrm{X}_{1}\right)$ sebesar 0,160 memiliki arti apabila variabel Literasi Keuangan $\left(\mathrm{X}_{1}\right)$ meningkat sebesar 1 satuan maka akan meningkatkan keputusan pengambilan kredit konsumtif (Y) sebesar 0,160. 
Koefisien parameter $\beta_{2}$ pada variabel Sifat Meterialisme $\left(\mathrm{X}_{2}\right)$ sebesar 0,325 memiliki arti apabila variabel Sifat Meterialisme $\left(\mathrm{X}_{2}\right)$ meningkat sebesar 1 satuan maka akan meningkatkan keputusan pengambilan kredit konsumtif (Y) sebesar 0,325.

Koefisien parameter $\beta_{3}$ pada variabel Jenis Kelamin $\left(\mathrm{X}_{3}\right)$ sebesar $-0,586$ memiliki arti tingkat keputusan pengambilan kredit konsumtif $(\mathrm{Y})$ untuk jenis kelamin laki-laki 0,586 point lebih rendah jika dibandingkan dengan tingkat keputusan pengambilan kredit konsumtif (Y) pada perempuan.

Koefisien parameter $\beta_{4}$ pada variabel Tingkat Pendidikan (S1) sebesar -0,371 memiliki arti tingkat keputusan pengambilan kredit konsumtif $(\mathrm{Y})$ untuk subjek yang berpendidikan terakhir S1 0,371 point lebih rendah jika dibandingkan dengan tingkat keputusan pengambilan kredit konsumtif (Y) pada subjek yang berpendidikan terakhir SMA.

Koefisien parameter $\beta_{5}$ pada variabel Tingkat Pendidikan (pasca) sebesar 0,480 memiliki arti tingkat keputusan pengambilan kredit konsumtif $(\mathrm{Y})$ untuk subjek yang berpendidikan terakhir pasca sarjana 0,480 point lebih tinggi jika dibandingkan dengan tingkat keputusan pengambilan kredit konsumtif $(\mathrm{Y})$ pada subjek yang berpendidikan terakhir SMA.

\subsection{Pembahasan}

\subsubsection{Literasi Keuangans}

Berdasarkan data yang sudah didapatkan dari lapangan kemudian dianalisis ditemukan bahwa literasi keuangan berpengaruh signifikan terhadap kepututsan pengambilan kredit konsumtif Aparatur Sipil Negara Kecamatan Lumajang. Literasi keuangan yang dimiliki Aparatur Sipil Negara Kecamatan Lumajang akan memberikan perilaku dalam pemenuhan kebutuhan konsumsi, investasi, asuransi, dan lain-lain. Pengetahuan tentang literasi keuangan yang dimiliki Aparatur Sipil Negara Kecamatan Lumajang, akan memberikan dampak dalam kehidupan sehari-hari mengenai perilaku dalam mengatur keuangan dan dalam memutuskan untuk mengambil kredit konsumtif. Pengetahuan literasi keuangan diterapkan pada proses keputusan pengambilan kredit konsumtif dalam rangka pemenuhan kebutuhan pribadi terkait kredit pemilikan rumah (KPR), kredit non-kpr (payday loan, kredit motor, pembelian gadget), dan kartu kredit \& kredit tanpa agunan. Semakin tinggi literasi keuangan maka individu akan semakin tepat dalam menentukan pengambilan keputusan kredit. Penelitian ini sejalan dengan penelitian yang dilakukan oleh (Aryani, 2020), Semakin tinggi literasi atau pengetahuan keuangan yang dimiliki oleh seorang nasabah maka dalam melakukan pengambilan keputusan kredit semakin baik, dan sebaliknya semakin rendah literasi keuangan maka perilaku keuangan semakin rendah, dimana hasilnya menunjukkan bahwa literasi keuangan berpengaruh positif dan signikan terhadap keputusan pengambilan kredit.

Aparatur Sipil Negara Kecamatan Lumajang memiliki literasi keuangan yang baik. Literasi keuangan yang balik merujuk pada kemampuan seseorang dalam menganalisis pengeluaran dan pendapatan yang diperolehnya. Hal ini dibuktikan dengan pernyataan literasi keuangan dari responden yang mayoritas memilih menjawab setuju. Dengan demikian, memiliki pengetahuan literasi keuangan dapat dengan mudah mengambil keputusan dengan bijak dan tidak akan menimbulkan masalah keuangan di masa mendatang. Sejalan dengan penelitian yang dilakukan oleh (Tsalitsa \& Rachmansyah, 2016), bahwa literasi keuangan yang 
baik yang akan membawa seseorang mencapai kesejahteraan bidang finansial. dengan beragam macam kebutuhan baik kebutuhan primer, sekunder maupun tersier akan dapat terpenuhi dengan tingkat literasi keuangan yang mereka miliki, dimana hasilnya literasi keuangan berpengaruh positif dan signifikan terhadap pengambilan kredit.

Literasi keuangan yang baik membuat individu bisa mengelola keuangan pribadi, sehingga bisa memperhitungkan ketika ingin mengambil kredit konsumtif. Pemahaman literasi keuangan juga bisa membuat individu mengetahui tentang produk-produk keuangan khususnya dalam pemilihan produk kredit. Individu yang mengetahui produk kredit yang ditawarkan bank dan bisa meminimalisir resiko dan memilih keuntungan dari kredit yang diambilnya. Individu yang memiliki literasi keuangan yang baik mampu meminimalisir kejadian gagal bayar kredit. Sejalan dengan penelitian yang dilakukan oleh (Darmawan \& Fatiharani, 2019), dalam penelitiannya menyatakan literasi keuangan yang baik dapat ditunjukkan dengan tingkat pemahaman mengenai produk dan konsep keuangan melalui bantuan informasi dan saran, sebagai kemampuan untuk mengidentifikasi dan memahami risiko keuangan agar dapat mengambil keputusan keuangan secara tepat, hasilnya menunjukkan literasi keuangan berpengaruh secara positif dan signifikan terhadap keputusan mengambil kredit.

\subsubsection{Sifat Materialisme}

Berdasarkan data yang sudah didapatkan di lapangan kemudian dianalisis ditemukan bahwa sifat materialisme berpengaruh signifikan terhadap keputusan pengambilan kredit konsumtif Aparatur Sipil Negara Kecamatan Lumajang. Sifat materialisme dalam pengambilan kredit konsumtif bisa dikatakan berpengaruh, jika individu memiliki sikap materialisme yang tinggi maka membuat individu memiliki rasa keinginan untuk membeli benda-benda berharga semakin tinggi dan kuat. Aparatur Sipil Negara Kecamatan Lumajang memiliki sifat materialisme yang tinggi, hal tersebut mendorong mereka untuk mengambil kredit konsumtif dikarenakan kemudahan proses dan jaminan ketika mengambil kredit. Hal ini dibuktikan dengan pernyataan sifat materialisme dari responden yang mayoritas memilih menjawab setuju yang mana pernyataan mempunyai nilai negatif. Sifat materialisme mendorong individu untuk memiliki kredit sebagai cara memuaskan keinginananya yang kuat. Hasil ini sesuai dengan penelitian yang dilakukan oleh (Limbu et al., 2012), (Zainudin et al., 2019), dan (Pradhan et al., 2018), bawha materialisme berpengaruh positif dan signifikan terhadap penggunaan kartu kredit

Persoalan sifat materialisme yang dimiliki individu adalah ketika merasa ingin dipandang oleh seseorang dan bagaimana sesorang ingin memandang dirinya dengan hal yang bersifat material. Seseorang yang materialistik berekspektasi jika memiliki barang yang mewah akan merasa dirinya memiliki derajat lebih tinggi, hal ini sesuai dengan hasil penelitian yang dilakukan (Liao \& Wang, 2009), bahwa materialistis lebih memungkinkan menggunakan pembelian untuk meningkatkan status sosial mereka, sebagai salah satu bentuk transformasi diri. Pelaku materialisme rela berkorban besar terhadap resiko keuangan pribadi demi mengejar barang keinginan untuk kepuasan semata, bahkan bersedia untuk memiliki hutang yang besar apabila keuangan tidak mencukupi. Sifat materialisme mendorong konsumen untuk membeli barang konsumtif, sehingga timbul rangsangan untuk segera menyalurkan keinginannya, mengurangi kemampuan untuk membatasi keinginan membeli yang terkadang bisa membuat timbul perasaan kecewa menimbulkan keadaan kurang puas dalam dirinya. 
Perilaku materialisme akan mengesampingkan pengendalian diri, membuat individu yang bersangkutan memiliki kecenderungan untuk berkonsumsi ketika ada alat konsumsi yang mudah diakses seperti kredit konsumtif.

Materialisme mempengaruhi perilaku konsumen dalam mengambil keputusan keuangan. Implikasi dari perilaku materialisme membuat konsumen memiliki sifat kecenderungan membeli, sehingga sering membebani diri mereka dengan hutang yang membuat keuangan pribadi menjadi bermasalah dan bisa mengakibatkan memiliki masalah emosional. Mempunyai keingan untuk membeli barang yang tidak bisa ditolak, penundaan hasrat ingin memiliki barang tertentu yang tidak bisa dipertahankan, menyebabkan individu dengan materialisme tinggi mengambil kredit untuk memenuhi kepuasan. Penelitian ini sejalan dengan penelitian yang dilakukan oleh (Ponchio \& Aranha, 2008), materialisme berpengaruh terhadap kredit yang mengindikasikan materialisme dikaitkan dengan kesediaan untuk menerima tingkat hutang yang lebih besar, hasil penelitian ini juga didukung oleh penelitian (Richins, 2011), bahwa materialisme terkait atau berpengaruh signifikan terhadap kredit, menyatakan hubungan antara materialisme dan perilaku kredit seharusnya menjadi relatif mudah. namun, untuk orang yang sudah menikah atau mitra yang berbagi tanggung jawab keuangan, gambarannya adalah lebih kompleks karena kewajiban kredit dibagi. Untuk misalnya, orang yang rendah materialisme mungkin hanya menerima sedikit kewajiban kreditnya sendiri, tetapi jika suaminya telah menghasilkan banyak hutang, dia mungkin memiliki banyak kekhawatiran kredit dan terlambat dalam pembayaran hutang karena perilaku pasangannya.

\subsubsection{Gender}

Berdasarkan data yang sudah didapatkan di lapangan kemudian dianalisis ditemukan bahwa gender tidak berpengaruh terhadap keputusan pengambilan kredit konsumtif Aparatur Sipil Negara Kecamatan Lumajang. Menurut data laki-laki dan perempuan memiliki jumlah yang sama banyak, hal ini menunjukkan bahwa terdapat perbedaan karakter atau peran dalam rumah tangga yang menyebabkan perbedaan dalam mengambil kredit antara laki-laki dan perempuan. Gender merupakan kategorisasi untuk membedakan antara perempuan dan lakilaki yang melakukan keputusan pengambilan kredit karena kebutuhan yang harus dipenuhi bukan berdasarkan pembeda jenis kelaminnya. Perbedaan dalam mengambil keputusan membuat laki-laki mengambil kredit karena pendapatan dan pengeluaran lebih besar yang merupakan kepala rumah tangga memikul beban tanggung jawab besar dalam urusan beban kewajiban keuangannya, sedangkan perempuan terkadang mengambil kredit untuk mencukupi kebutuhan akibat minimnya pendapatan yang diterima dari suami ataupun kebutuhan pribadi.

Penelitian ini sesuai dengan penelitian yang dilakukan oleh (Rita \& Kusumawati, 2015), bahwa variabel sosio demografi (jenis kelamin) tidak mempengaruhi sikap, norma subjektif dan kontrol perilaku menggunaan kartu kredit. Penelitian ini sesuai dengan penelitian yang dilakukan (Nitawati, 2020), bahwa gender tidak berpengaruh terhadap keputusan mengambil kredit, Hal ini menepis anggapan bahwa gender atau jenis kelamin menjadi alasan utama yang mempengaruhi seseorang dalam mengambil keputusan mengambil kredit. Penelitian ini tidak sesuai dengan penelitian yang dilakukan oleh (Hamriah, 2019), yang menyatakan bahwa gender berpengaruh secara positif dan signifikan terhadap keputusan pengambilan kredit. 


\subsubsection{Tingkat Pendidikan}

Berdasarkan data yang sudah didapatkan di lapangan kemudian dianalisis ditemukan bahwa tingkat pendidikan tidak berpengaruh terhadap keputusan pengambilan kredit konsumtif Aparatur Sipil Negara Kecamatan Lumajang. Tingkat pendidikan di dalam instansi Aparatur Sipil Negara Kecamatan Lumajang antara satu dengan yang lainnya berbeda, hal ini yang membuat perbedaan dalam memutuskan untuk pengambilan keputusan suatu kredit. Tingkat pendidikan merupakan pembeda jenjang pendidikan terakhir yang telah ditempuh seseorang, dalam melakukan keputusan pengambilan kredit baik jenjang pendidikan tinggi atau rendah memiliki peluang untuk mengajukan kredit. Pendidikan mempengaruhi individu dalam mengambil keputusan, pendidikan memberikan pengetahuan dan sikap yang diambil individu terhadap keputusan mereka dalam memahami kredit konsumtif yang akan diambil. Ketika akan mengambil kredit seseorang yang berpendidikan tinggi akan memperhitungkan kemampuan membayar, tingkat bunga yang dikenakan, manfaat kredit, dan resiko keuangan pribadi di kemudian hari, sedangkan individu yang mempunyai pendidikan rendah akan kurang mengerti terhadap resiko dan keuntungan kredit yang diambil.

Sesuai dengan penelitian yang dilakukan oleh (Rita \& Kusumawati, 2015), menyatakan bahwa pendidikan memiliki pengaruh negatif dan signifikan terhadap pengambilan kredit, yang berarti bahwa semakin tinggi pendidikan seseorang maka penggunaan kartu kreditnya akan semakin menurun. Penelitian ini sejalan dengan penelitian yang dilakukan oleh (Nitawati, 2020), bahwa pendidikan tidak berpengaruh terhadap pengambilan keputusan kredit, Hal ini mematahkan anggapan bahwa semakin tinggi tingkat pendidikan seseorang maka semakin tinggi kemungkinan untuk mengambil keputusan melakukan kredit. Tingkat pendidikan saat ini bukan syarat dasar atau utama suatu lembaga menilai kelayakan dalam pengambilan kredit sehingga baik seseorang dengan tingkat pendidikan tinggi maupun rendah memiliki kesempatan dan kemungkinan untuk mengajukan kredit. Penelitian ini sejalan dengan penelitian yang dilakukan oleh (Tsalitsa \& Rachmansyah, 2016), bahwa terdapat pengaruh negatif dan signifikan dari variabel bebas yaitu pendidikan terhadap variabel terikat yaitu pengambilan kredit, yang berarti menandakan bahwa semakin tinggi pendidikan maka semakin rendah pengambilan kreditnya dikarenakan individu lebih berhati-hati terhadap pengelolaan dan pengeluaran uang yang dimilikinya serta melihat dari sisi kebermanfaatannya dan begitu pula sebaliknya.

\section{Simpulan}

\subsection{Kesimpulan}

Berdasarkan hasil analisis dan pembahasan dalam penelitian ini, maka peneliti mengambil mengambil kesimpulan bahwa literasi keuangan yang dimiliki Aparatur Sipil Negara Kecamatan Lumajang secara keseluruhan berada dalam kategori baik. Literasi keuangan berpengaruh secara signifikan baik secara parsial atau simultan terhadap keputusan pengambilan kredit konsumtif. Hal ini menunjukkan bahwa tingkat literasi yang tinggi akan mempengaruhi individu dalam memahami keuntungan dan resiko kredit khususnya kredit konsumtif yang akan diambil, sehingga tidak menimbulkan masalah gagal bayar kredit dan masalah keuangan yang mungkin bisa terjadi. Literasi keuangan yang baik mampu membuat individu memahami dasar-dasar ilmu ekonomi khusunya dalam mengatur keuangan pribadi, sehingga dapat membuat keputusan yang bijak dan tepat. 
Sifat materialisme berpengaruh signifikan baik secara parsial atau simultan terhadap keputusan pengambilan kredit konsumtif. Pengaruh positif dan signifikan tersebut memiliki arti, apabila semakin tinggi sifat materialisme yang dimiliki seseorang maka kecenderungan untuk mengambil kredit konsumtif semakin meningkat. Materialisme yang tinggi membuat kebutuhan untuk menunjukkan eksistensi di masyarakat membuat individu mengambil kredit konsumtif apabila keuangan mereka kurang memadai dan menginginkan dana secara cepat.

Gender tidak berpengaruh secara parsial terhadap keputusan pengambilan kredit konsumtif, tetapi berpengaruh secara simultan terhadap keputusan pengambilan kredit. Dalam penelitian ini jumlah laki-laki dan perempuan sama banyaknya. Gender merupakan kategorisasi untuk membedakan antara perempuan dan laki-laki untuk melakukan keputusan pengambilan kredit karena kebutuhan yang harus dipenuhi bukan berdasarkan pembeda jenis kelaminnya.

Tingkat pendidikan tidak berpengaruh secara parsial terhadap keputusan pengambilan kredit konsumtif, tetapi berpengaruh secara simultan terhadap keputusan pengambilan kredit konsumtif. Tingkat pendidikan merupakan pembeda jenjang pendidikan terakhir yang telah ditempuh seseorang, dalam melakukan keputusan pengambilan kredit baik jenjang pendidikan tinggi atau rendah memiliki peluang untuk mengajukan kredit.

\subsection{Keterbatasan}

Berdasarkan penelitian yang telah dilakukan penelitian ini harus disempurnakan karena memiliki beberapa keterbatasan. Keterbatasan tersebut antara lain:

Kurangnya refrensi terkait literasi keuangan dan sifat materialisme yang masih minim khususnya pada lembaga pemerintahan.

Kurangnya peneliti tentang koordinasi pengambilan data kuesioner sehingga peneliti kesulitan untuk mengawasi langsung agar hasil yang didapat sempurna.

Kurangnya pengetahuan peneliti tentang alat analisis untuk menyesuaikan perbedaan skala pada variabel peneltian sehingga peneliti mengalami kesulitan

\subsection{Saran}

Berdasarkan hasil penelitian maka penulis memberikan saran sebagai berikut:

Bagi Masyarakat diharapkan masyarakat dalam mengambil kredit konsumtif untuk lebih mengutamakan kebutuhan yang memberikan keuntungan dan membuat produktif dengan melihat kemampuan membayar sehingga tidak terjadi gagal bayar.

Bagi Peneliti Selanjutnya diharapkan apabila ingin meniliti keputusan pengambilan kredit konsumtif dapat memfokuskan kepada literasi keuangan dan sifat materialisme, serta menambahkan atau meninjau dari faktor-faktor lain seperti lingkungan, pendapatan terakhir, usia, status pernikahan, usia, kontrol perilaku, atau faktor lainnya. Selain itu, diharapkan memilih responden yang jangkauannya lebih luas bukan hanya pada lembaga pemerintahan, dengan menyusun kuesioner sesuai refrensi yang lebih akurat, sehingga hasil yang didapatkan menggambarkan subjek dengan baik. Serta penggunaan alat ukur tidak hanya berupa instrument kuesinoer dengan cara analisis kuantitatif, tetapi dapat berupa data dan 
wawancara dengan cara kualitatif. Kombinasi antara kuantitatif dan kualitatif dalam penelitian ini akan mendapatkan hasil yang lebih akurat, tidak terjadi perbedaan persepsi antara peneliti dengan responden.

\section{Daftar Rujukan}

Afif, N., Ubaidillah, A., \& Sulhan, M. (2020). Konsep Kesetaraan Gender Perspektif Fatima Mernissi dan Implikasinya dalam Pendidikan Islam. IQ (Ilmu Al-Qur'an): Jurnal Pendidikan Islam, 3(02), 229-242.

Arikunto, S. (2002). Prosedur Penelitian Suatu Pendekatan Praktek, Cet. Ke-12. Jakarta. Rineka Cipta.

Aryani, D. (2020). PENGARUH LITERASI DAN INKLUSI KEUANGAN TERHADAP KEPUTUSAN PENGAMBILAN KREDIT. IIB DARMAJAYA.

Badan Kepegawaian Daerah. (n.d.). Pemerintah Kabupaten Lumajang Rekapitulasi Data Kepegawaian. https://bkd.lumajangkab.go.id/dashboard/index.php

Bank Indonesia. (n.d.-a). Pertumbuhan Kredit Baru Triwulan IV 2020 Diprakirakan Meningkat. Www.Bi.Go.Idd. https://www.bi.go.id/id/ruang-media/info-terbaru/Pages/Pertumbuhan-Kredit-Baru-Triwulan-IV2020-Diprakirakan-Meningkat.aspx

Bank Indonesia. (n.d.-b). Survei Perbankan Triwulan I 2020 Pertumbuhan Triwulanan Kredit Baru Melambat. Www.Bi.Go.Id. https://www.bi.go.id/id/ruang-media/info-terbaru/Pages/Survei-PerbankanTriwulan-I-2020-Pertumbuhan-Triwulanan-Kredit-Baru-Melambat.aspx

Bank Indonesia. (n.d.-c). Survei Perbankan Tw II - 2020 : Pertumbuhan Kredit 2020 Diprakirakan Melemah. Www.Bi.Go.Id. https://www.bi.go.id/id/ruang-media/info-terbaru/Pages/Survei-Perbankan-Tw-II2020-Pertumbuhan-Kredit-2020-Diprakirakan-Melemah.aspx

Bungin, P. D. H. M. B., \& Sos, S. (2005). Metodologi Penelitian Kuantitatif: Edisi Kedua. Kencana.

Chen, H., \& Volpe, R. P. (1998). An analysis of personal financial literacy among college students. Financial Services Review, 7(2), 107-128.

Chinen, K., \& Endo, H. (2012). Effects of attitude and background on personal financial ability: A student survey in the United States. International Journal of Management, 29(1), 33.

Cloutier, J., \& Roy, A. (2020). Consumer Credit Use of Undergraduate, Graduate and Postgraduate Students: An Application of the Theory of Planned Behaviour. Journal of Consumer Policy, 1-28.

Collins, R. (1988). Women and men in the class structure. Journal of Family Issues, 9(1), 27-50.

Darmawan, A., \& Fatiharani, D. (2019). LITERASI KEUANGAN, FAKTOR DEMOGRAFI DAN AKSES PERMODALAN PENGARUHNYA TERHADAP KEPUTUSAN PENGAMBILAN KREDIT USAHA SEKTOR INFORMAL.

databoks. (2020). Nilai Transaksi Kartu Kredit Indonesia Terus Meningkat. https://databoks.katadata.co.id/datapublish/2020/04/28/nilai-transaksi-kartu-kredit-indonesiaterus-meningkat

de Matos, C. A., Vieira, V., Bonfanti, K., \& Mette, F. M. B. (2019). Antecedents of indebtedness for low-income consumers: the mediating role of materialism. Journal of Consumer Marketing.

Ergün, K. (2018). Financial literacy among university students: A study in eight European countries. International Journal of Consumer Studies, 42(1), 2-15.

Hadad, M. D., Santoso, W., \& Alisjahbana, A. (2004). Model dan Estimasi Permintaan dan Penawaran Kredit Konsumsi Rumah Tangga di Indonesia. Bi. Go. Id, 1-26.

Hafizhah, I., Basri, Y. M., \& Rusli, R. (2016). Pengaruh Etika Uang (Money Ethics) terhadap Kecurangan Pajak (Tax Evasion) dengan Religiusitas, Gender, dan Materialisme sebagai Variabel Moderasi (Studi pada Wp Op yang Melakukan Kegiatan USAha atau Pekerjaan Bebas di Pekanbaru). Riau University.

Hamriah, H. (2019). Pengaruh Literasi Keuangan dan Gender terhadap Pengambilan Keputusan Kredit pada PT. Bank Rakyat Indonesia (Persero) Tbk Cabang Panakkukang Makassar. Universitas Islam Negeri Alauddin Makassar.

Handayani, T., Sugiarti, \& Dharma, S. (2008). Konsep dan teknik: penelitian gender. Universitas Muhammadiyah Malang (UMM) Press.

Hao, Y., Liu, S., Jiesisibieke, Z. L., \& Xu, Y.-J. (2019). What determines university students' online consumer credit? Evidence from China. SAGE Open, 9(1), 2158244019833594. 
Indonesia, G. B. (2005). Peraturan Bank Indonesia Nomor: 7/2/pbi/2005 Tentang Penilaian Kualitas Aktiva Bank umum. Bank of Indonesia Regulation, 7/2.

Indonesia, Pemerintah Republik. (2014). Undang-Undang Republik Indonesia Nomor 5 Tahun 2014 tentang Aparatur Sipil Negara.

Indonesia, Presiden Republik. (2003). Undang-undang Republik Indonesia nomor 20 tahun 2003 tentang sistem pendidikan nasional. Jakarta: Pemerintah Republik Indonesia.

Iqbal, N., \& Aslam, N. (2016). Materialism, Depression, and Compulsive Buying among University Students. International Journal of Indian Psychology, 3(2), 91-102.

Kasmir. (2016). Bank dan Lembaga Keuangan Lainnya (Edisi Revi). Jakarta: Rajawali Pers.

Kotler, P. dan G. A. (2008). Prinsip-prinsip Pemasaran (Edisi 12 J). Erlangga.

Liao, J., \& Wang, L. (2009). Face as a mediator of the relationship between material value and brand consciousness. Psychology \& Marketing, 26(11), 987-1001.

Limbu, Y. B., Huhmann, B. A., \& Xu, B. (2012). Are college students at greater risk of credit card abuse? Age, gender, materialism and parental influence on consumer response to credit cards. Journal of Financial Services Marketing, 17(2), 148-162.

Lusardi, A., \& Mitchell, O. S. (2014). The economic importance of financial literacy: Theory and evidence. Journal of Economic Literature, 52(1), 5-44.

Mason, C. L. J., \& Wilson, R. M. S. (2000). Conceptualising fi-financial literacy. Occasional Paper, 7.

Mueller, A., Claes, L., Mitchell, J. E., Faber, R. J., Fischer, J., \& de Zwaan, M. (2011). Does compulsive buying differ between male and female students? Personality and Individual Differences, 50(8), 1309-1312.

Nitawati, E. Y. (2020). LITERASI KEUANGAN DAN KARAKTERISTIK SOSIODEMOGRAFI TERHADAP PENGAMBILAN KEPUTUSAN KREDIT. Jurnal Manajemen STIE ABI Surabaya, 2(2).

Ponchio, M. C., \& Aranha, F. (2008). Materialism as a predictor variable of low income consumer behavior when entering into installment plan agreements. Journal of Consumer Behaviour: An International Research Review, 7(1), 21-34.

Pradhan, D., Israel, D., \& Jena, A. K. (2018). Materialism and compulsive buying behaviour: The role of consumer credit card use and impulse buying. Asia Pacific Journal of Marketing and Logistics.

Priyatno, D. (2018). SPSS Panduan Mudah Olah Data Bagi Mahasiswa \& Umum. Yogyakarta: Andi.

Richins, M. L. (2011). Materialism, transformation expectations, and spending: Implications for credit use. Journal of Public Policy \& Marketing, 30(2), 141-156.

Riduwan, M. B. A. (2010). Metode dan teknik menyusun tesis. Bandung: Alfabeta.

Rita, M. R., \& Kusumawati, R. (2015). Pengaruh variabel sosio demografi dan karakteristik finansial terhadap sikap, norma subyektif dan kontrol perilaku menggunakan kartu kredit (studi pada pegawai di UKSW Salatiga). Jurnal Manajemen Dan Keuangan, 9(2), 109-128.

Rohrke, A., \& Robinson, L. (2000). Guide to Financial Literacy Resources. Journal of Financial Literacy.

Sari, F. K. (2016). PENGARUH KUALITAS PELAYANAN DAN PROSEDUR KREDIT TERHADAP KEPUTUSAN PENGAMBILAN KREDIT DENGAN REFERENCE GROUP SEBAGAI VARIABEL MODERATING PADA BADAN KREDIT DESA (BKD) GOMBONG. Universitas Negeri Yogyakarta.

Schiffman, L., \& Kanuk, L. L. (2008). Perilaku Konsumen edisi ketujuh. Jakarta (ID): PT Index Group.

Setiawan, K., \& Kusrini, E. (2010). Ekonometrika. CV, Andi Offset, Yogyakarta, 55281, 10-12.

Tsalitsa, A., \& Rachmansyah, Y. (2016). Analisis pengaruh literasi keuangan dan faktor demografi terhadap pengambilan kredit pada PT. Columbia cabang kudus. Media Ekonomi Dan Manajemen, 31(1).

UNDANG-UNDANG REPUBLIK INDONESIA NOMOR 5 TAHUN 2014 TENTANG APARATUR SIPIL NEGARA. (n.d.). https://jdih.kemenkeu.go.id/fulltext/2014/5TAHUN2014UU.htm

Winatha, R. G., \& Sukaatmadja, I. P. G. (2014). Pengaruh Sifat Materialisme Dan Kecanduan Internet Terhadap Perilaku Pembelian Impulsif Secara Online. Udayana University.

Yushita, A. N. (2017). Pentingnya literasi keuangan bagi pengelolaan keuangan pribadi. Nominal: Barometer Riset Akuntansi Dan Manajemen, 6(1), 11-26. 
Jurnal Ekonomi, Bisnis dan Pendidikan, 1(9), 2021, 889-905

Zahara, I. (1981). Dasar-dasar kependidikan. Padang: Angkasa Raya.

Zainudin, R., Mahdzan, N. S., \& Yeap, M.-Y. (2019). Determinants of credit card misuse among Gen Y consumers in urban Malaysia. International Journal of Bank Marketing. 